\title{
Efficient processing of cassava starch: physicochemical characterization at different processing parameters
}

\author{
*Ma'aruf, A.G. and Abdul, H.R. \\ School of Chemical Sciences and Food Technology, Faculty of Science and Technology, Universiti \\ Kebangsaan Malaysia, 43600 Bangi, Selangor
}

\begin{abstract}
Article history:
Received: 21 June 2019

Received in revised form: 15 August 2019

Accepted: 17 August 2019

Available Online: 27 August 2019
\end{abstract}

\section{Keywords:}

Starch processing,

Physicochemical,

Drying temperature,

Milling size,

Paste viscosity,

Gel strength

DOI:

https://doi.org/10.26656/fr.2017.4(1).235

\begin{abstract}
The aim of this study was to evaluate the physicochemical properties of cassava starch that was processed using different parameters (types of water, drying temperatures and milling sizes) to be added into the food products as an ingredient. Selected commercial cassava starch was used as a reference. Mineral water showed a significantly higher value $(p<0.05)$ for the paste viscosity of cassava starch compared to the other types of water, but indicated no significant difference $(\mathrm{p}>0.05)$ with tap water for the swelling power, solubility and gel strength of cassava starch. The increase in the drying temperature significantly decreased $(\mathrm{p}<0.05)$ swelling power, paste viscosity and gel strength of cassava starch but significantly increased $(p<0.05)$ its solubility. The increase in the milling size significantly increased $(\mathrm{p}<0.05)$ swelling power and solubility, paste viscosity and gel strength of cassava starch. For industrial benefits, the use of mineral water for starch processing, the lowest drying temperature of $70^{\circ} \mathrm{C}$ and the largest milling size of 63 $\mu \mathrm{m}$ shall be the best processing parameters to produce cassava starch with the highest swelling power which could act as a reliable expansion aid in food products. These parameters shall also be the best processing parameters to produce cassava starch with the highest paste viscosity which could function as a desirable food thickening or gelling agent, as well as the highest gel strength that could be applied as an excellent texture enhancer, binder, or coating for food products.
\end{abstract}

\section{Introduction}

Cassava, scientifically known as Manihot Esculenta Cranz, is a type of plant that is consumed across the world as one of the main sources of carbohydrates and as a staple food (Alves, 2001). The ability of cassava plants to survive and grow on lands with low water supply, fertilizers and agrochemical inputs allows easier, costeffective cultivation and management (Okudoh et al., 2014). Starch, which is a functional major component of cassava roots, is usually dried and ground into dry powder form to increase its shelf life and facilitate its uses for many applications (Falade and Akingbala, 2010). Various applications of starch in food production have made it a highly demanded raw material by consumers and manufacturers. Starch can be used as a thickening agent, gelling agent (Berski et al., 2011), binder, texture enhancer (Beggs et al., 1997; Pietrasik, 1999), crispiness enhancer and coating (Gaines et al., 2000) in many edible and non-edible products. However, some problems may emerge on the end product of cassava starch manufacturing where the quality of cassava starch could be unfit for applications in food products that use cassava starch as an ingredient. The quality of starch could be determined by its physicochemical properties which represent the functionality of starch (Adebowale and Lawal, 2002). For instance, commercial cassava starch produced by a local starch manufacturer in Malaysia that was used as a reference in this experiment showed very low paste viscosity that could render it less suitable to be applied as thickener and gelling agent in food (Berski et al., 2011) and very low gel strength that may hinder its capacity as a texture enhancer in food products like frozen surimi products (Liu et al., 2014). These problems eventually may lead to fewer consumers' acceptance and loss of profits. For these reasons, the need to inquire into processing factors that may lower the quality of cassava starch has emerged so that these factors can be controlled or modified in order to meet the quality standards that are highly anticipated by consumers or manufacturers.

Potential involuntary changes of physicochemical properties of the cassava starch could be induced by processing factors such as types of water, drying temperature and milling size as proven from previous 
researches. Different types of water may affect the physicochemical properties of starch due to the differences in mineral ion contents and concentrations which was proven to have remarkable effects on the properties of starch. The types of water generally used in starch processing are mineral water and household tap water. Mineral water, commonly known as hard water has a lot of dissolved ions, especially ions of calcium and magnesium (Gumashta et al., 2012). This water is abundant in nature and could be economical for manufacturers. Tap water is commonly used but could be costing more to manufacturers since the costs for water supplies and maintenance would be involved. Calcium ions, for instance, increase the swelling power of starch (Jiang et al., 2012) and viscosity of the starch paste (Jane, 1993; Samutsri and Suphantharika, 2012), while sodium ions decrease the swelling power of starch (Oosten, 1990; Hedayati et al., 2016) and viscosity of starch paste (Hedayati et al., 2016). Different drying temperatures were reported to have effects on the physicochemical properties of starch as well. Higher drying temperature reportedly causes lower swelling power and solubility of starch (Aviara et al., 2010; Akintunde and Tunde-Akintunde, 2013) and lower viscosity of starch paste (Alam and Hasnain, 2009). Besides that, different milling sizes also could influence the physicochemical properties of starch as smaller milling size reportedly causes lower swelling power (Noranizan et al., 2010), paste viscosity and gel strength (Hossen et al., 2011). Study on the effects of processing parameters on physicochemical properties of cassava starch seems to be scant. Thus, a need to investigate the influences of processing factors such as types of water, drying temperature and milling size on the changes in physicochemical properties of cassava starch such as swelling power, solubility, paste viscosity, and gel strength emerges as these changes may restrict the application of cassava starch in food production. Cassava starch manufacturing industry can benefit from this research through the knowledge for process modification in order to attain cassava starch with desirable qualities such as higher swelling power, paste viscosity, and gel strength which could be more applicable in the food industry.

The objective of our study was to investigate the effects of three processing parameters: different types of water, drying temperatures, and milling sizes on the physicochemical properties of cassava starch. The physicochemical properties of cassava starch evaluated were swelling power and solubility, paste viscosity, and gel strength.

\section{Materials and methods}

\subsection{Raw materials}

Cassava roots of Manihot Esculenta Cranz species with the same variety (peat cassava plants were grown in Banting, Selangor, Malaysia and harvested in April 2016) were obtained, peeled and washed with filtered clean water. Then, they were chopped into thin slices of $1 \mathrm{~cm}$ thickness (Oduro-Yeboah et al., 2010) for further starch sample preparation. Cassava starch obtained from Bio Starch Industries Worldwide Sdn. Bhd., Malaysia was labeled as commercial starch (cassava roots were from the variety of clay-loam cassava plants grown in Perak, Malaysia, wholly processed using underground water from Section 51A, Petaling Jaya, Selangor, Malaysia). This commercial starch had particle size distribution of industrial starch at $0.29 \mu \mathrm{m}$ based on particle size analysis carried out by Kim et al. (2004) and was used as a reference to the other cassava starch samples produced through different processing parameters.

The deionized water was obtained using Arium Pro DI Type 1 Ultrapure Water Quality Systems (Sartorius AG, Göttingen, Germany). The deionized water was selected as a controlled sample or a blank solution to be compared to the other types of water due to its very low mineral content (Mazurova et al., 2015). The tap water was obtained from food pilot plant of Universiti Kebangsaan Malaysia. Mineral water used was Spritzer mineral water from the underground source at Taiping, Perak, Malaysia. Tap water and underground mineral water were selected because they are abundant and generally used in food industries. Plus, selected commercial starch was also processed using 100\% underground water.

\subsection{Analytical measurement for different types of water}

Analyses for $\mathrm{pH}$ value and mineral content were conducted on different types of water which were deionized water, tap water, and mineral water. The $\mathrm{pH}$ value of the water was determined by using a $\mathrm{pH}$ meter (Kulthanan et al., 2013). The analysis of the mineral content of water was carried out according to the method by Voica et al. (2013).

\subsection{Preparation of cassava starch}

Cassava starch extraction was carried out by means of sedimentation (Oduro-Yeboah et al., 2010) with some modifications. Sliced cassava root was ground with tap water for 10 mins to obtain 1:2 cassava roots to water mixture (modification was made here by replacing tap water with deionized water and mineral water to yield three different types of water). The resulting semi-liquid starch slurry was filtered through cheesecloth to separate 
the pulp from semi-liquid starch milk collected in the filtrate. The rinsing process was repeated three times to ensure there was little or no starch in the semi-liquid pulp. Isolated starch milk was left for $15 \mathrm{hrs}$ for sedimentation and then the supernatant liquid was poured out. The starch layer was visible as it deposited on the bottom. The starch layer was scraped off and dried in an oven for $7 \mathrm{hrs}$ at $70^{\circ} \mathrm{C}$ (modification was made here by substituting the drying temperature of $70^{\circ}$ $\mathrm{C}$ with $80^{\circ} \mathrm{C}, 90^{\circ} \mathrm{C}, 100^{\circ} \mathrm{C}$ to yield four different drying temperatures) and milled using a mortar and pestle. Milled starch was sifted using a sieve with $63 \mu \mathrm{m}$ opening size (modification was made here by substituting the $63 \mu \mathrm{m}$ sieve with $45 \mu \mathrm{m}$ and $53 \mu \mathrm{m}$ sieves to yield three different milling sizes) and then stored in clean labeled containers with the tight lid.

The milling sizes of $45 \mu \mathrm{m}, 53 \mu \mathrm{m}$, and $63 \mu \mathrm{m}$ were selected because they complied with Codex Standard for Edible Cassava Flour by indicating particle size of flour starch lower than $600 \mu \mathrm{m}$ (FAO and WHO, 2013). Selection of drying temperatures was based on some experimental reasons. Drying temperatures of $70^{\circ} \mathrm{C}$ and $80^{\circ} \mathrm{C}$ were chosen according to drying temperatures for starchy flour which had been used by Ajala et al. (2014), Njintang and Mbofung (2006), and Sanni and Jaji (2003). Drying temperatures of $90^{\circ} \mathrm{C}$ and $100^{\circ} \mathrm{C}$ were selected to investigate whether the drying temperatures higher than $80^{\circ} \mathrm{C}$ could have the benefit or harmful effect on the physicochemical properties of cassava starch apart from improving the efficiency of the drying process for cassava starch.

\subsection{Swelling power and solubility}

Swelling power and solubility of cassava starch sample had been determined using the method of Leach et al. (1959). The solution of $1 \%$ starch by weight/ volume in distilled water was heated in a water bath shaker for 30 mins at $85^{\circ} \mathrm{C}$. Water bath temperature of $85^{\circ} \mathrm{C}$ was selected because, at this heating temperature, starch began to thicken and became translucent (Shariffa et al., 2017). Centrifuge tubes were covered with a plastic cover when heated to prevent water loss. After heating, the sample was centrifuged at $3000 \mathrm{rpm}$ for 15 mins. The precipitated paste was separated from the supernatant and weighed (Wp). Both precipitated paste and supernatant were dried at $105^{\circ} \mathrm{C}$ for $24 \mathrm{hrs}$ and subsequently weight of dry precipitated paste (Wps) and dried supernatant (Ws) were recorded. Swelling power is defined as the ratio of swollen starch after centrifugation to dry swollen starch. Solubility is defined as the percentage of dry soluble solids in the supernatant to the dry weight of the whole starch sample (Wo).

Swelling power $=\mathrm{Wp} / \mathrm{Wps}$ (wet precipitated starch $(\mathrm{g}) /$ dry precipitated starch $(\mathrm{g}))$

Solubility $=(\mathrm{Ws} / \mathrm{Wo}) \times 100 \%($ soluble solids $(\mathrm{g}) / \mathrm{dry}$ weight of whole starch sample $(\mathrm{g}))$

\subsection{Paste viscosity}

Cassava starch solution was prepared based on the technique used by Reddy and Bhotmange (2014). The $2 \%$ starch solution was heated until it boiled at $100^{\circ} \mathrm{C}$ for 20 mins with even stirring and then cooled to room temperature $\left(25^{\circ} \mathrm{C}\right)$ while continually stirred. The paste viscosity test of cassava starch solution was carried out based on the techniques proposed by Rohaya et al. (2013) and the readings were taken as Pascal-second (Pa.s) unit.

\subsection{Gel strength}

The gel strength analysis was carried out in accordance with the technique performed by Noranizan et al. (2010). About $10 \%$ by weight/volume of evenly stirred aqueous starch suspension was heated in a boiling water bath at $100^{\circ} \mathrm{C}$ while stirred continuously until the viscosity increased when the resulting starch paste reached $80^{\circ} \mathrm{C}$. The hot starch paste was poured into plastic containers $(4.5 \mathrm{~cm}$ diameter) to $3 \mathrm{~cm}$ height. Paraffin oil was immediately poured on the surface of this starch paste to prevent loss of moisture and then it was stored at room temperature $\left(25 \pm 2^{\circ} \mathrm{C}\right)$ for $24 \mathrm{hrs}$. The resulting gel strength of cooled starch paste was measured using the Shimadzu AGS-J Texture Analyzer (Shimadzu Corp., Kyoto, Japan). Gel with its container was placed on the compression platform. A $20 \mathrm{~mm}$ diameter cylindrical ebonite probe (P10) was then driven at a constant speed $(5 \mathrm{~mm} / \mathrm{s})$ into the gel for $10 \mathrm{~mm}$ depth. Trigger force was set at $5 \mathrm{~g}$ and the first peak was recorded as the gel strength. Reading was expressed in Newton (N) unit.

\subsection{Statistical analysis}

Values obtained from different processing parameters were expressed as mean with a standard deviation from triplicate determinations. Data were analyzed by analysis of variance using SPSS Statistics version 23. Differences between starch samples were considered significant at $\mathrm{p}<0.05$.

\section{Results and discussion}

3.1 Effect of different types of water on physicochemical properties of cassava starch

The $\mathrm{pH}$ value of different types of water was presented in Table 1 while the mineral contents of different types of water were shown in Table 2 . When starch granules are heated in excess water, they swell due 
to water uptake and increase in size (Singh et al., 2003). The deionized water showed the lowest swelling power of cassava starch compared to the other types of water, including commercial starch (Table 3), which could be due to its lowest $\mathrm{pH}$ (Table 1) that increases the amount of intermolecular bonding between the starch polymers and decreases the interaction of starch polymers with water, hence reduces ability of starch to swell (Hoover and Ratnayake, 2002). Besides that, the starch undergoes partial gelatinization in more alkaline condition and then increases the swelling power of starch compared to lower $\mathrm{pH}$ condition that is less alkaline (Adebowale and Lawal, 2005). The deionized water also showed the lowest swelling power of cassava starch compared to the other types of water due to its lowest calcium ions content (Table 2) that reduces water absorption by starch granules and inhibits their ability to swell (Jiang et al., 2012). The commercial starch and cassava starch treated with both mineral water and tap water displayed higher swelling power and shall be more suitable to be applied as an expansion aid in food products comparison to cassava starch treated with deionized water. These starch samples could be fit for food products such as keropok lekor, Malaysian fluffy and chewy fish crackers that expand upon boiling and local thin fish crackers that expand upon hot deep frying due to entrapment of water molecules inside the swollen starch granules (Cheow et al., 2004; Noranizan et al., 2010). Furthermore, cassava starch with higher swelling power also forms a less hard texture of food by trapping more water in starch molecules (Muthia et al., 2010).

Table 1. The $\mathrm{pH}$ value of different types of water

\begin{tabular}{cc}
\hline Type of water & $\mathrm{pH}$ value \\
\hline Deionized & $7.09 \pm 0.01^{\mathrm{a}}$ \\
Tap & $7.39 \pm 0.01^{\mathrm{b}}$ \\
Mineral & $7.50 \pm 0.02^{\mathrm{c}}$ \\
\hline
\end{tabular}

The values are the average of triplicate analysis with \pm SD. Mean values having different superscript in a column are significantly different $(\mathrm{p}<0.05)$.

The solubility of starch represents the percentage of leached amylose and amylopectin from starch granules when starch is heated above gelatinization temperature (Waterschoot et al., 2014). The lowest solubility of cassava starch shown by deionized water compared to tap water and mineral water (Table 3 ) could be due to its lowest $\mathrm{pH}$ value (Table 1) that limits partial starch gelatinization, hence reduces swelling power and solubility of starch, unlike at higher $\mathrm{pH}$ (Adebowale and Lawal, 2005). This result opposed the finding reported by Builders et al. (2014), which stated that a $\mathrm{pH}$ condition which is higher than 7 reduces the solubility of tiger nut starch. The highest solubility of cassava starch treated with mineral water may indicate weakest bonding forces within starch granules (Aryee et al., 2006) compared to the cassava starch samples treated with other types of water and commercial starch.

Table 2 . The mineral content for different types of water

\begin{tabular}{lccc}
\hline \multirow{2}{*}{$\begin{array}{c}\text { Type of mineral } \\
\text { ion }\end{array}$} & \multicolumn{3}{c}{ Mineral content (ppm) } \\
\cline { 2 - 4 } & $\begin{array}{c}\text { Deionized } \\
\text { water }\end{array}$ & Tap water & Mineral water \\
\hline Calcium & $0.50 \pm 0.00^{\mathrm{a}}$ & $9.68 \pm 0.00^{\mathrm{b}}$ & $18.04 \pm 0.06^{\mathrm{c}}$ \\
Magnesium & $\mathrm{ND}$ & $1.18 \pm 0.01^{\mathrm{a}}$ & $3.42 \pm 0.01^{\mathrm{b}}$ \\
Sodium & $0.29 \pm 0.00^{\mathrm{a}}$ & $9.46 \pm 0.11^{\mathrm{b}}$ & $9.16 \pm 0.10^{\mathrm{c}}$ \\
Potassium & $0.11 \pm 0.00^{\mathrm{a}}$ & $4.66 \pm 0.05^{\mathrm{b}}$ & $2.83 \pm 0.03^{\mathrm{c}}$ \\
Aluminum & $\mathrm{ND}$ & $0.02 \pm 0.00^{\mathrm{a}}$ & $\mathrm{ND}$ \\
Arsenic & $\mathrm{ND}$ & $\mathrm{ND}$ & $\mathrm{ND}$ \\
Barium & $\mathrm{ND}$ & $0.02 \pm 0.00^{\mathrm{a}}$ & $\mathrm{ND}$ \\
Boron & $0.02 \pm 0.00^{\mathrm{a}}$ & $0.02 \pm 0.00^{\mathrm{a}}$ & $0.01 \pm 0.00^{\mathrm{a}}$ \\
Chromium & $\mathrm{ND}$ & $\mathrm{ND}$ & $\mathrm{ND}$ \\
Iron & $\mathrm{ND}$ & $0.07 \pm 0.00^{\mathrm{a}}$ & $0.13 \pm 0.01^{\mathrm{b}}$ \\
Uranium & $\mathrm{ND}$ & $\mathrm{ND}$ & $\mathrm{ND}$ \\
Strontium & $\mathrm{ND}$ & $0.03 \pm 0.00^{\mathrm{a}}$ & $0.11 \pm 0.00^{\mathrm{a}}$ \\
Zinc & $\mathrm{ND}$ & $0.01 \pm 0.00^{\mathrm{a}}$ & $\mathrm{ND}$ \\
Antimony & $\mathrm{ND}$ & $\mathrm{ND}$ & ND \\
\hline
\end{tabular}

The values are the average of triplicate analysis with \pm SD. Mean values having different superscript in a column are significantly different $(\mathrm{p}<0.05)$.

Table 3. Swelling power, solubility, paste viscosity and gel strength of cassava starch processed with different types of water

\begin{tabular}{llccc}
\hline $\begin{array}{c}\text { Type of } \\
\text { water }\end{array}$ & $\begin{array}{c}\text { Swelling } \\
\text { power }(\mathrm{g} / \mathrm{g})\end{array}$ & $\begin{array}{c}\text { Solubility } \\
(\%)\end{array}$ & $\begin{array}{c}\text { Paste } \\
\text { viscosity } \\
(\text { Pa.s) }\end{array}$ & $\begin{array}{c}\text { Gel } \\
\text { strength } \\
(\mathrm{N})\end{array}$ \\
\hline Deionized & $22.44 \pm 0.81^{\mathrm{a}}$ & $12.79 \pm 0.55^{\mathrm{a}}$ & $0.42 \pm 0.01^{\mathrm{a}}$ & $0.77 \pm 0.05^{\mathrm{a}}$ \\
Tap & $25.64 \pm 0.37^{\mathrm{b}}$ & $18.63 \pm 0.55^{\mathrm{b}}$ & $1.04 \pm 0.03^{\mathrm{b}}$ & $0.85 \pm 0.02^{\mathrm{b}}$ \\
Mineral & $26.29 \pm 0.34^{\mathrm{b}}$ & $19.25 \pm 1.51^{\mathrm{b}}$ & $1.17 \pm 0.07^{\mathrm{c}}$ & $0.87 \pm 0.01^{\mathrm{b}}$ \\
$\begin{array}{l}\text { Commercial } \\
\text { starch }\end{array}$ & $25.37 \pm 0.61^{\mathrm{b}}$ & $13.30 \pm 1.26^{\mathrm{a}}$ & $0.23 \pm 0.03^{\mathrm{d}}$ & $0.48 \pm 0.02^{\mathrm{c}}$ \\
\hline
\end{tabular}

The values are the average of triplicate analysis with \pm SD. Mean values having different superscript in a column are significantly different $(\mathrm{p}<0.05)$.

The lowest paste viscosity shown by cassava starch treated with deionized water compared to the other types of water (Table 3 ) could be due to its lowest calcium ions content (Table 2) that could reduce the absorption of water into the starch granules and inhibit the formation of intramolecular cross-linkage effects on the starch polymer chains (Jane, 1993; Samutsri and Suphantharika, 2012). Sodium ions can compete with starch to bind water and cause electrostatic interactions between starch and sodium ions (Oosten, 1990; Samutsri and Suphantharika, 2012) and therefore, led to lower paste viscosity of cassava starch treated with tap water compared to mineral water. Viscosity shown by starch paste may contribute to its role as a thickening agent or gelling agent in food products (Berski et al., 2011). Cassava starch treated with mineral water and tap water could be promoted as the thickening and gelling agents in food (Berski et al., 2011) especially in sauce products that require high stability during storage (Sikora et al., 2007), instead of selected commercial starch and also 
Table 4. Swelling power, solubility, paste viscosity and gel strength of cassava starch with different drying temperatures

\begin{tabular}{ccccc}
\hline Drying temperature $\left({ }^{\circ} \mathrm{C}\right)$ & Swelling power $(\mathrm{g} / \mathrm{g})$ & Solubility $(\%)$ & Paste viscosity $($ Pa.s) & Gel strength $(\mathrm{N})$ \\
\hline 70 & $24.57 \pm 0.56^{\mathrm{a}}$ & $13.87 \pm 0.38^{\mathrm{a}}$ & $0.98 \pm 0.00^{\mathrm{a}}$ & $0.45 \pm 0.03^{\mathrm{a}}$ \\
80 & $22.03 \pm 0.43^{\mathrm{b}}$ & $15.49 \pm 0.38^{\mathrm{b}}$ & $0.82 \pm 0.01^{\mathrm{b}}$ & $0.34 \pm 0.01^{\mathrm{b}}$ \\
90 & $21.95 \pm 0.37^{\mathrm{b}}$ & $18.18 \pm 0.42^{\mathrm{c}}$ & $0.66 \pm 0.02^{\mathrm{c}}$ & $0.30 \pm 0.01^{\mathrm{bc}}$ \\
100 & $21.17 \pm 0.09^{\mathrm{b}}$ & $18.81 \pm 0.42^{\mathrm{c}}$ & $0.45 \pm 0.01^{\mathrm{d}}$ & $0.27 \pm 0.02^{\mathrm{c}}$ \\
Commercial starch & $25.37 \pm 0.61^{\mathrm{a}}$ & $13.30 \pm 1.26^{\mathrm{a}}$ & $0.23 \pm 0.03^{\mathrm{e}}$ & $0.48 \pm 0.02^{\mathrm{a}}$ \\
\hline
\end{tabular}

The values are the average of triplicate analysis with \pm SD. Mean values having different superscript in a column are significantly different $(\mathrm{p}<0.05)$.

cassava starch treated with deionized water. The commercial starch showed the lowest paste viscosity compared to those starch samples treated with all three types of water, so it is not suitable to be applied as a thickener or gelling agent.

When cooked starch paste undergoes the cooling process, leached amylose and amylopectin re-associate to form the irreversible starch gel (Lu et al., 2007). The lowest gel strength of cassava starch shown by deionized water compared to tap water and mineral water (Table 3) could be due to lower calcium ions content (Table 2) that could reduce interaction between the molecules of starch and thereby, weaken starch gel (Hedayati et al., 2016). Cassava starch treated with tap water and mineral water could be ideal to be applied as food coating, binder (Gaines et al., 2000), texture enhancer, and chewiness enhancer for various food products, such as sausages and surimi products (Beggs et al., 1997; Pietrasik, 1999) instead of cassava starch treated with deionized water and selected commercial starch. The commercial starch displayed the lowest gel strength compared to those cassava starch samples treated with all three types of water, and hence, its application in food shall be discouraged.

Although selected commercial starch was processed using underground water, it indicated very low paste viscosity and gel strength compared to the sample of cassava starch processed with mineral water, which was obtained from the underground source too. This possibly could be due to treatment with different kinds of underground water and other possible processing factors, such as probably unfit drying temperature used for commercial starch (Akintunde and Tunde-Akintunde, 2013; Mustafa Kamal et al., 2017) and its very small milling size of $0.29 \mu \mathrm{m}$ (Hossen et al., 2011). By modifying the milling size or drying temperature, the commercial starch manufacturer could enhance the quality of its cassava starch so that higher paste viscosity and gel strength of starch can be obtained.

\subsection{Effect of different drying temperatures on} physicochemical properties of cassava starch

The highest swelling power of cassava starch shown by the lowest drying temperature of $70^{\circ} \mathrm{C}$ compared to higher drying temperatures (Table 4) could be due to more loss of crystalline structure of starch, amylose leaching and rearrangement of molecules in starch granules caused by higher drying temperatures (Chung et al., 2000). Both commercial starch and cassava starch dried at $70^{\circ} \mathrm{C}$ may have the good potential to be applied as an expansion aid in food products due to their high swelling power (Cheow et al., 2004; Noranizan et al., 2010) compared to those treated with other higher drying temperatures.

Cassava starch dried at the lowest temperature of $70^{\circ}$ C displayed the lowest solubility compared to higher drying temperatures (Table 4), which may be due to loss of granular structure and crystallinity of starch at higher drying temperatures that allow easier leaching of starch molecules out of the starch granules (Li et al., 2014). The commercial starch showed very low solubility that did not differ significantly ( $p>0.05)$ from cassava starch dried at $70^{\circ} \mathrm{C}$, which could be due to possibly improper drying temperature for commercial starch (Akintunde and Tunde-Akintunde, 2013; Mustafa Kamal et al., 2017) or due to the breakdown of starch granules on the starch molecules from the grinding process to obtain its very small milling size of $0.29 \mu \mathrm{m}$ (Hossen et al., 2011).

Higher drying temperatures caused lower paste viscosity of cassava starch (Table 4) because higher drying temperatures can cause more broken hydrogen bonds in starch granules (Aviara et al., 2010) and lead to more losses of granular structure that render starch to be less viscous (Alam and Hasnain, 2009). The cassava starch dried at the lowest drying temperature of $70^{\circ} \mathrm{C}$ showed the highest paste viscosity and could be ideal to be applied as a thickening agent compared to those dried higher temperatures. The commercial starch shall not be suitable as a thickening agent due to its very low paste viscosity of starch. Since the drying temperature of commercial cassava starch was undetermined, modification can be made by the commercial starch manufacturer by reducing the drying temperature presently used so that higher paste viscosity of starch can be achieved.

The highest gel strength was indicated by cassava starch dried at $70^{\circ} \mathrm{C}$ compared to the other higher drying 
temperatures (Table 4). This could be due to the fact that higher drying temperatures cause more soluble substances to leach out of starch granules, including water. The starch dried at very high temperature already lost the soluble substances and produced more dilute gel when being heated in water (Noranizan et al., 2010). Higher drying temperatures also caused the breakdown of starch granules and reduced its ability to hold water. Thus, lower gel strength of starch was produced (Wang, 1997). The cassava starch dried at $70^{\circ} \mathrm{C}$ and also commercial starch could have the good capacity to be applied as food coating (Gaines et al., 2000), binder and texture enhancer (Beggs et al., 1997; Pietrasik, 1999) in food products due to higher gel strength compared to the other cassava starch treated with higher drying temperatures.

\subsection{Effect of different milling sizes on physicochemical properties of cassava starch}

The lowest swelling power indicated by cassava starch with the smallest milling size of $45 \mu \mathrm{m}$ compared to larger milling sizes (Table 5) could be due to the grinding process which caused the breakdown of starch polymer chains into smaller fragments and eventually reduced the ability of starch to absorb water and swell (Hossen et al., 2011). The grinding process to obtain smaller milling size also reduced the swelling power of cassava starch due to loss of solids into the supernatant that minimized the ability of starch to absorb water (Kerr et al., 2000). Compared to cassava starch samples with the larger milling sizes of $53 \mu \mathrm{m}$ and $63 \mu \mathrm{m}$, commercial starch and cassava starch with milling size of $45 \mu \mathrm{m}$ are not suitable for use as an expansion aid and volume enhancer in food products.

Table 5. Swelling power, solubility, paste viscosity and gel strength of cassava starch with different milling sizes

\begin{tabular}{ccccc}
\hline $\begin{array}{c}\text { Milling size } \\
(\mu \mathrm{m})\end{array}$ & $\begin{array}{c}\text { Swelling } \\
\text { power }(\mathrm{g} / \mathrm{g})\end{array}$ & $\begin{array}{c}\text { Solubility } \\
(\%)\end{array}$ & $\begin{array}{c}\text { Paste } \\
\text { viscosity } \\
(\text { Pa.s })\end{array}$ & $\begin{array}{c}\text { Gel } \\
\text { strength } \\
(\mathrm{N})\end{array}$ \\
\hline 45 & $27.6 \pm 0.42^{\mathrm{a}}$ & $20.20 \pm 1.50^{\mathrm{a}}$ & $0.82 \pm 0.01^{\mathrm{a}}$ & $0.78 \pm 0.01^{\mathrm{a}}$ \\
53 & $32.21 \pm 0.57^{\mathrm{b}}$ & $22.29 \pm 1.39^{\mathrm{a}}$ & $0.86 \pm 0.01^{\mathrm{b}}$ & $0.84 \pm 0.03^{\mathrm{b}}$ \\
63 & $33.47 \pm 1.95^{\mathrm{b}}$ & $25.48 \pm 0.51^{\mathrm{b}}$ & $0.90 \pm 0.01^{\mathrm{b}}$ & $0.94 \pm 0.02^{\mathrm{c}}$
\end{tabular}

Commercial $25.37 \pm 0.61^{\mathrm{a}} \quad 13.30 \pm 1.26^{\mathrm{c}} \quad 0.23 \pm 0.03^{\mathrm{c}} \quad 0.48 \pm 0.02^{\mathrm{d}}$

The values are the average of triplicate analysis with \pm SD. Mean values having different superscript in a column are significantly different $(\mathrm{p}<0.05)$.

Cassava starch with the largest milling size of $63 \mu \mathrm{m}$ showed the highest solubility compared to the other lower milling sizes and commercial starch (Table 5). This could be due to higher swelling power of the starch granules that allowed more starch molecules to be leached out of the granules and thereby increased the solubility of the starch molecules (Srichuwong et al.,
2005). The lowest solubility that was shown by commercial starch may indicate the least leaching of the starch molecule from granules, which could be due to its very low swelling power.

The lowest paste viscosity exhibited by cassava starch with the lowest milling size of $45 \mu \mathrm{m}$ compared to those with larger milling sizes (Table 5) could be due to breakdown of starch granules into smaller fragments during grinding that prevented water from being completely absorbed by the starch and reduced the paste viscosity of starch (Hossen et al., 2011). The commercial starch exhibited the lowest paste viscosity than all other milling sizes of cassava starch, which could be due to its smallest milling size $(0.29 \mu \mathrm{m})$, hence rendered it the least ideal starch to be applied as a thickening agent in food. The use of larger milling sizes of cassava starch of $53 \mu \mathrm{m}$ and $63 \mu \mathrm{m}$ as thickening agents could be promoted owing to their higher paste viscosity compared to the milling size of $45 \mu \mathrm{m}$ and commercial starch.

According to Table 5, the larger the milling size of cassava starch, the higher its gel strength. This is because dry grinding caused the breakdown of the starch polymer chains and reduced the retrogradation ability of starch and finally reduced its gel strength (Ahmad et al., 2016). Thus, cassava starch with the largest milling size (63 $\mu \mathrm{m})$ will be suitable as food binder and texture enhancer in food. The commercial starch showed the lowest gel strength due to its very small milling size of $0.29 \mu \mathrm{m}$ and thereby could be unfit for food application.

Compared to cassava starch samples with larger milling sizes such as $53 \mu \mathrm{m}$ and $63 \mu \mathrm{m}$, the commercial starch showed very low swelling power, paste viscosity and gel strength (Table 5), which may restrict its application in food products and cause loss of profits to the commercial starch manufacturer. It is recommended that the commercial starch manufacturer could use larger milling size in order to obtain better qualities of commercial cassava starch in terms of swelling power, paste viscosity, and gel strength.

\section{Conclusion}

Mineral water showed a significantly higher value $(p<0.05)$ for paste viscosity of cassava starch compared to the other types of water, but showed no significant difference $(p>0.05)$ with tap water for the swelling power, solubility and gel strength of cassava starch. The rise in the drying temperature significantly reduced $(p<0.05)$ swelling power, gel strength and paste viscosity of cassava starch, but significantly increased $(p<0.05)$ its solubility. Increasing the milling size significantly increased $(p<0.05)$ swelling power and solubility, gel strength and paste viscosity of cassava starch. For 
industrial advantages, the best processing parameters to produce cassava starch with the highest swelling power are the use of mineral water for cassava starch processing, the lowest drying temperature of $70^{\circ} \mathrm{C}$ and the largest milling size of $63 \mu \mathrm{m}$, which could act as an excellent expansion aid in food products. These parameters shall also be the best processing parameters for producing cassava starch with the highest paste viscosity that could function as a decent food thickening and gelling agent, as well as the highest gel strength that could be used as an excellent texture enhancer, binder, or coating in food products. A more extensive research to clarify the effects of different concentration for single types of mineral ions, such as calcium, magnesium, potassium, and sodium, on the physicochemical properties of cassava starch is suggested as different types and concentrations of mineral ions may show distinct effects on the physicochemical properties of cassava starch, such as swelling power, paste viscosity, and gel strength.

\section{Conflict of Interest}

Authors declare no conflict of interest.

\section{Acknowledgments}

The authors are thankful to the Faculty of Science and Technology, Universiti Kebangsaan Malaysia for providing the research grant (TPU-33) and the research facilities.

\section{References}

Adebowale, K.O. and Lawal, O.S. (2002). Effect of annealing and heat-moisture conditioning on the physicochemical characteristics of bambara groundnut (Voandzeia subterranean) starch. Nahrung/Food, 46(5), 311-316. https:// doi.org/10.1002/1521-3803(20020901) 46:5<311::AID-FOOD311>3.0.CO;2-Z

Adebowale, K.O. and Lawal, O.S. (2005). An assessment of changes in thermal and physicochemical parameters of jack bean (Canavalia ensiformis) starch following hydrothermal modifications. European Food Research and Technology, 221(5), 631-638. https:// doi.org/10.1007/s00217-005-0032-z

Ahmad, N., Rajab, A. and Mohd Hani, N. (2016). Effects of different grinding methods on morphological, textural properties and pasting profiles of MR220 rice flour. Malaysian Journal of Analytical Sciences, 20(3), 585-593. https://doi.org/10.17576/mjas-20162003-18

Ajala, A.S., Ogunsola, A.D. and Odudele, F.B. (2014).
Evaluation of drying temperature on proximate, thermal and physical properties of cocoyam flour. Global Journal of Engineering, Design and Technology, 3(4), 13-18.

Akintunde, B.O. and Tunde-Akintunde, T.Y. (2013). Effect of drying method and variety on quality of cassava starch extracts. African Journal of Food, Agriculture, Nutrition and Development, 13(5), 8351 $-8367$.

Alam, F. and Hasnain, A. (2009). Studies on swelling and solubility of modified starch from taro (Colocasia esculenta): Effect of $\mathrm{pH}$ and temperature. Agriculturae Conspectus Scientificus, 74(1), 45-50.

Alves, A.A.C. (2002). Cassava Botany and Physiology. In Hillocks, R.J., Thresh, J.M. and Bellotti, A. (Eds). Cassava: Biology, Production and Utilization, p. 6789. UK: CABI Pub. https:// doi.org/10.1079/9780851995243.0067

Aryee, F.N.A., Oduro, I., Ellis, W.O. and Afuakwa, J.J. (2006). The physicochemical properties of flour samples from the roots of 31 varieties of cassava. Food Control, 17(11), 916-922. https:// doi.org/10.1016/j.foodcont.2005.06.013

Aviara, N.A., Igbeka, J.C. and Nwokocha, L.M. (2010). Physicochemical properties of sorghum (Sorghum bicolor 1. Moench) starch as affected by drying temperature. Agricultural Engineering International: CIGR Journal, 12(2), 85-94.

Beggs, K.L.H., Bowers, J.A. and Brown, D. (1997). Sensory and physical characteristics of reduced-fat turkey frankfurters with modified corn starch and water. Journal of Food Science, 62(6), 1240-1244. https://doi.org/10.1111/j.1365-2621.1997.tb12253.x

Berski, W., Ptaszek, A., Ptaszek, P., Ziobro, R., Kowalski, G., Grzesik, M. and Achremowicz, B. (2011). Pasting and rheological properties of oat starch and its derivatives. Carbohydrate Polymers, 83(2), 665-671. https://doi.org/10.1016/ j.carbpol.2010.08.036

Builders, F.B., Mbah, C.C., Adama, K.K. and Audu, M.M. (2014). Effect of $\mathrm{pH}$ on the physicochemical and binder properties of tigernut starch. Starch/ Stärke, 66(3-4), 281-293. https://doi.org/10.1002/ star.201300014

Cheow, C.S., Kyaw, Z.Y., Howell, N.K. and Dzulkifly, M.H. (2004). Relationship between physicochemical properties of starches and expansion of fish cracker 'keropok'. Journal of Food Quality, 27(1), 1-12. https://doi.org/10.1111/j.1745-4557.2004.tb00633.x

Chung, K.M., Moon, T.W. and Chun, J.K. (2000). Influence of annealing on gel properties of mung bean starch. Cereal Chemistry, 77(5), 567-571. 
https://doi.org/10.1094/CCHEM.2000.77.5.567

Falade, K.O. and Akingbala, J.O. (2010). Utilization of cassava for food. Food Reviews International, 27(1), 51-83. https:// doi.org/10.1080/87559129.2010.518296

FAO and WHO (2013). Codex standard for edible cassava flour 176-1989. Retrieved from http:// www.fao.org/input/download/standards/59/ CXS_176e.pdf

Gaines, C.S., Raeker, M.Ö., Tilley, M., Finney, P.L., Wilson, J.D., Bechtel, D.B., Martin, R.J., Seib, P.A., Lookhart, G.L. and Donelson, T. (2000). Associations of starch gel hardness, granule size, waxy allelic expression, thermal pasting, milling quality, and kernel texture of 12 soft wheat cultivars. Cereal Chemistry, 77(2), 163-168. https:// doi.org/10.1094/CCHEM.2000.77.2.163

Gumashta, J., Gumashta, R. and Sadawarte, S.K. (2012). Hard water and heart: the story revisited. IOSR Journal of Pharmacy and Biological Sciences, 1(1), 7-20. https://doi.org/10.9790/3008-0110720

Hedayati, S., Majzoobi, M., Shahidi, F. Koocheki, A. and Farahnaky, A. (2016). Effects of $\mathrm{NaCl}$ and $\mathrm{CaCl}_{2}$ on physicochemical properties of pregelatinized and granular cold-water swelling corn starches. Food Chemistry, 213, 602-608. https:// doi.org/10.1016/j.foodchem.2016.07.027

Hoover, R. and Ratnayake, W.S. (2002). Starch characteristics of black bean, chick pea, lentil, navy bean and pinto bean cultivars grown in Canada. Food Chemistry, 78(4), 489-498. https:// doi.org/10.1016/S0308-8146(02)00163-2

Hossen, M.S., Sotome, I., Takenaka, M., Isobe, S., Nakajima, M. and Okadome, H. (2011). Effect of particle size of different crop starches and their flours on pasting properties. Japan Journal of Food Engineering, 12(1), 29-35. https://doi.org/10.11301/ jsfe. 12.29

Jane, J.L. (1993). Mechanism of starch gelatinization in neutral salt solutions. Starch/Stärke, 45(5), 161-166. https://doi.org/10.1002/star.19930450502

Jiang, X., Jiang, T., Gan, L., Zhang, X., Dai, H. and Zhang, X. (2012). The plasticizing mechanism and effect of calcium chloride on starch/poly (vinyl alcohol) films. Carbohydrate Polymers, 90(4), 1677 -1684. https://doi.org/10.1016/j.carbpol.2012.07.050

Kerr, W.L., Ward, C.D.W., McWatters, K.H. and Resurrecion, A.V.A (2000). Effect of milling and particle size on functionality and physicochemical properties of cowpea flour. Cereal Chemistry, 77(2), 213-219. https://doi.org/10.1094/
Kim, W., Choi, S.G., Kerr, W.L., Johnson, J.W. and Gaines, C.S. (2004). Effect of heating temperature on particle size distribution in hard and soft wheat flour. Journal of Cereal Science, 40(1), 9-16. https:// doi.org/10.1016/j.jcs.2004.04.005

Kulthanan, K., Nuchkull, P. and Varothai, S. (2013). The $\mathrm{pH}$ of water from various sources: An overview for recommendation for patients with atopic dermatitis. Asia Pacific Allergy, 3(3), 155-160. https:// doi.org/10.5415/apallergy.2013.3.3.155

Leach, H.W., McCowen, L.D. and Schoch, T.J. (1959). Structure of the starch granule.1. Swelling and solubility patterns of various starches. Cereal Chemistry, 36, 534-544.

Li, E., Dhital, S. and Hasjim, J. (2014). Effects of grain milling on starch structures and flour/starch properties. Starch-Stärke, 66(1-2), 15-27. https:// doi.org/10.1002/star.201200224

Liu, H., Nie. Y. and Chen, H. (2014). Effect of different starches on colors and textural properties of surimistarch gels. International Journal of Food Properties, 17(7), 1439- $1448 . \quad \mathrm{https} / /$ doi.org/10.1080/10942912.2012.680224

Lu, T., Duh, C., Lin, J. and Chang, Y. (2007). Effect of granular characteristics on the viscoelastic properties of composites of amylose and waxy starches. Food Hydrocolloids, 22(1), 164-173. https:// doi.org/10.1016/j.foodhyd.2007.04.001

Mazurova, I., Khvaschevskaya, A. and Guseva, N. (2015). The choice of conditions for the determination of vanadium, chromium and arsenic concentration in waters by ICP-MS using collision mode. Procedia Chemistry, 15, 201-205. https:// doi.org/10.1016/j.proche.2015.10.032

Mustafa Kamal, M., Baini, R., Mohamaddan, S., Selaman, O.S., Zauzi, N.A., Rahman, M.R., Abdul Rahim, N., Chong, K.H., Atan, M.F., Abdul Samat, N.A.S., Taib, S.N.L. and Othman, A.K. (2017). Effect of temperature to the properties of sago starch. Conference Series: Materials Science and Engineering, 206, 1-13. https://doi.org/10.1088/1757 $-899 X / 206 / 1 / 012039$

Muthia, D., Nurul, H. and Noryati, I. (2010). The effects of tapioca, wheat, sago and potato flours on the physicochemical and sensory properties of duck sausage. International Food Research Journal, 17 (4), 877-884.

Njintang, Y.N. and Mbofung, C.M.F. (2006). Effect of precooking time and drying temperature on the physico-chemical characteristics and in-vitro carbohydrate digestibility of taro flour. LWT - Food Science and Technology, 39(6), 684-691. https:// 
doi.org/10.1016/j.lwt.2005.03.022

Noranizan, M.A., Dzulkifly, M.H. and Russly, A.R. (2010). Effect of heat treatment on the physicochemical properties of starch from different botanical sources. International Food Research Journal, 17, 127-135.

Oduro-Yeboah, C., Johnson, P-N.T., Sakyi-Dawson, E. and Budu, A. (2010). Effect of processing procedures on the colorimetry and viscoelastic properties of cassava starch, flour and cassavaplantain fufu flour. International Food Research Journal, 17, 127-135.

Okudoh, V., Trois, C., Workneh, T. and Schmidt, S. (2014). The potential of cassava biomass and applicable technologies for sustainable biogas production in South Africa: A review. Renewable and Sustainable Energy Reviews, 39, 1035-1052. https://doi.org/10.1016/j.rser.2014.07.142

Oosten, B.J. (1990). Interactions between starch and electrolytes. Starch/Stärke, 42(9), 327-330. https:// doi.org/10.1002/star.19900420902

Pietrasik, Z. (1999). Effect of content of protein, fat and modified starch on binding textural characteristics, and colour of comminuted scalded sausages. Meat Science, 51(1), 17-25. https://doi.org/10.1016/S0309 -1740(98)00068-0

Reddy, D.K. and Bhotmange, M.G. (2014). Viscosity of starch: A comparative study of Indian rice (Oryza Sativa L.) varieties. International Review of Applied Engineering Research, 4(5), 397-402.

Rohaya, M.S., Maskat, M.Y. and Ma'aruf, A.G. (2013). Rheological properties of different degree of pregelatinized rice flour batter. Sains Malaysiana, 42 (12), 1707-1714.

Samutsri, W. and Suphantharika, M. (2012). Effect of salts on pasting, thermal, and rheological properties of rice starch in the presence of non-ionic and ionic hydrocolloids. Carbohydrate Polymers, 87(2), 15591568. https://doi.org/10.1016/j.carbpol.2011.09.055

Sanni, L.O. and Jaji, F.F. (2003). Effect of drying and roasting on the quality attributes of fufu powder. International Journal of Food Properties, 6(2), 229238. https://doi.org/10.1081/JFP-120017843

Shariffa, Y.N., Uthumporn, U., Karim, A.A. and Zaibunnisa, A.H. (2017). Hydrolysis of native and annealed tapioca and sweet potato starches at subgelatinization temperature using a mixture of amylolytic enzymes. International Food Research Journal, 24(5), 1925-1933.

Sikora, M., Kowalski, S., Tomasik, P. and Sady, M. (2007). Rheological and sensory properties of dessert sauces thickened by starch-xanthan gum combination. Journal of Food Engineering, 79(4), 1144-1151.

https://doi.org/10.1016/ j.jfoodeng.2006.04.003

Singh, N., Singh, J., Kaur, L., Sodhi, N.S. and GillI, B.S. (2003). Morphological, thermal and rheological properties of starches from different botanical sources. Food Chemistry, 81(2), 219-231. https:// doi.org/10.1016/S0308-8146(02)00416-8

Srichuwong, S., Sunarti, T.C., Mishima, T., Isono, N. and Hisamatsu, M. (2005). Starches from different botanical sources II: Contribution of starch structure to swelling and pasting properties. Carbohydrate Polymers, 62(1), 25-34. https://doi.org/10.1016/ j.carbpol.2005.07.003

Voica, C., Kovacs, M. and Feher, I. (2013). Studies on the content of heavy metals in Aries River using ICP -MS. AIP Conference Proceedings, 1565, 317-321. https://doi.org/10.1063/1.4833753

Wang, S.W. (1997). Starches and starch derivatives in expanded snacks. Cereal Foods World, 42(9), 743745.

Waterschoot, J., Gomand, S.V., Fierens, E. and Delcour, J.A. (2014). Production, structure, physicochemical and functional properties of maize, cassava, wheat, potato and rice starches. Starch - Stärke Special Issue: General Reviews, 67(1-2), 14-29. https:// doi.org/10.1002/star.201300238 